\title{
Function of the Dufour's gland in solitary and social Hymenoptera
}

\author{
Aniruddha Mitra ${ }^{1,2}$ \\ I Department of Biology, Washington University in St Louis, St. Louis, MO 63130-4899, U.S.A. 2 Present \\ address: TA-09, New Biology Building, Centre for Ecological Sciences, Indian Institute of Science, Bangalore \\ - 560012, India
}

Corresponding author: Aniruddha Mitra (mitra.aniruddha@gmail.com)

Academic editor: Jack Neff| Received 29 January 2013 | Accepted 28 August 2013 | Published 25 October 2013

Citation: Mitra A (2013) Function of the Dufour's gland in solitary and social Hymenoptera. Journal of Hymenoptera Research 35: 33-58. doi: 10.3897/JHR.35.4783

\begin{abstract}
The poison gland and Dufour's gland are the two glands associated with the sting apparatus in female Apocrita (Hymenoptera). While the poison gland usually functions as an integral part of the venom delivery system, the Dufour's gland has been found to differ in its function in various hymenopteran groups. Like all exocrine glands, the function of the Dufour's gland is to secrete chemicals, but the nature and function of the secretions varies in different taxa. Functions of the Dufour's gland secretions range from serving as a component of material used in nest building, larval food, and pheromones involved in communicative functions that are important for both solitary and social species. This review summarizes the different functions reported for the Dufour's gland in hymenopterans, illustrating how the Dufour's gland secretions can be adapted to give rise to various functions in response to different challenges posed by the ways of life followed by different taxa. Aspects of development, structure, chemistry and the evolution of different functions are also touched upon briefly.
\end{abstract}

\section{Keywords}

Dufour's gland, function, structure, chemistry, evolution, Hymenoptera

\section{Introduction}

The poison gland and Dufour's gland are the two glands associated with the sting apparatus in female Apocrita (Hymenoptera) (Fig 1). The Dufour's gland is generally found in most Apocrita, and in Symphyta a homologous gland may exist (Robertson 1968, Van Marle and Piek 1986).

Copyright Aniruddha Mitra. This is an open access article distributed under the terms of the Creative Commons Attribution License 3.0 (CC-BY), which permits unrestricted use, distribution, and reproduction in any medium, provided the original author and source are credited 


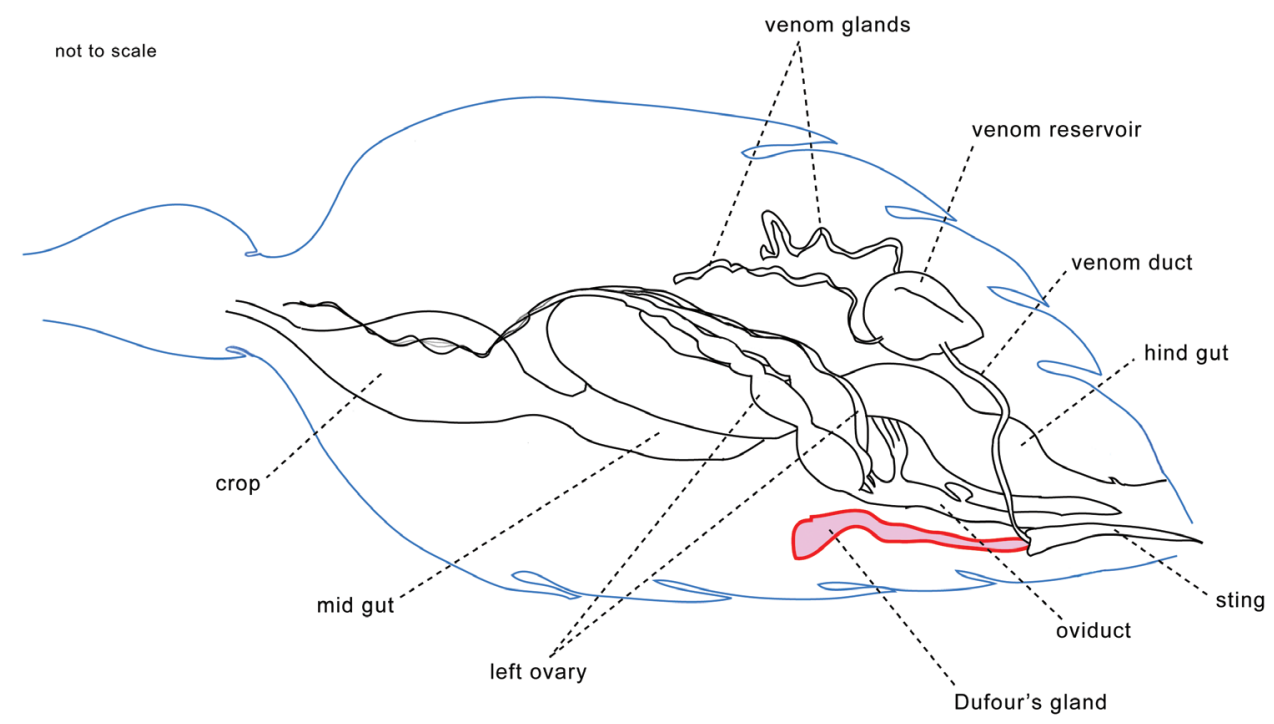

Figure I. Diagram showing position of the Dufour's gland among other abdominal organs in the polistine wasp Ropalidia marginata. (Drawing: author, not to scale)

Hymenopterans probably originated during the Triassic period (about 250 to 200 million years ago), and the oldest fossils found are similar to sawflies of the family Xyelidae (Symphyta) (Rasnitsyn 2002). The Hymenoptera started diversifying during the Cretaceous (about 150 to 70 million years ago), and this diversification took place simultaneously with other major insect groups like the Lepidoptera, Coleoptera and Diptera, in conjunction with the the rise of the flowering plants, signifying plant-insect coevolution (Hoell et al. 1998, Grimaldi and Engel 2005). The first social Hymenoptera are also believed to have evolved in the Cretaceous. Although the establishment of the major hymenopteran categories like Apocrita, Aculeata and non-aculeate Apocrita, and the subsequent split between ancestors of present day aculeates (Apoidea, Vespoidea and Chrysidoidea) appears to have taken place earlier, in the Jurassic (about 200 to 150 million years ago) (Rasnitsyn and Zhang 2010, Heraty et al. 2011), much of the diversification appears to have taken place in the Cretaceous, when the major Aculeate clades became established (Brady et al. 2009). Thus the Dufour's gland may have been evolving for over more than 200 million years to give rise to the variety of functions it exhibits in modern hymenopterans.

While the poison gland usually functions as an integral part of the venom delivery system, used for paralyzing prey to be used as food as well as in defense, the Dufour's gland has been found to differ in its function in various hymenopteran groups. Like all exocrine glands, the function of the Dufour's gland is to secrete chemicals, but the nature and function of the secretions varies in different taxa. Functions of the Dufour's gland secretions range from serving as a component of material used in nest building, larval food, and various communicative functions like host marking, nest recognition, nestmate recognition, kin recognition, fertility signaling, as a trail pheromone and as a 
sex pheromone. These are important for both solitary and social species. The purpose of this review is to summarize the different functions reported for the Dufour's gland secretions in hymenopterans. This will further the understanding and appreciation of how an organ can be adapted for different functions in different lineages, and how differences in the mode of living has led to an organ being adapted for diverse functions. Aspects of development, structure and chemistry are also touched upon briefly.

\section{Development and structure}

The Dufour's gland (often referred to as "alkaline gland" in the older literature) was first described by Dufour (1841). It is an ectodermal abdominal gland located near the proximal end of the abdomen (Fig. 1), and is believed to be a homologue of the colleterial gland of other insects, i.e. an accessory reproductive gland (Carlet 1884, Maschwitz and Kloft 1971, Hermann 1969, Hermann and Blum 1967a, 1967b, 1981, Abdalla and Cruz-Landim 2001). The sting apparatus in Hymenoptera is ectodermal in origin and arises as a modification of the female reproductive system, as evidenced from developmental ontogeny. Buds of genitalia develop on the $8^{\text {th }}$ and $9^{\text {th }}$ abdominal sterna of hymenopteran larvae, and these develop into the ovipositor (sting). The spermatheca, poison gland and Dufour's glands develop as invaginations of valves of the sternum (D'Rozario 1942, Robertson 1968). The duct of the Dufour's gland opens into the sting in ants, while in wasps and bees it opens into the dorsal vaginal wall. The duct opening into the vaginal wall has been proposed as the ancestral state, while opening into the sting has been proposed as a derived state (Billen 1987). However, in a digger wasp, it has been reported that the Dufour's gland opens into the sting, thereby raising doubts about the earlier hypothesis (Gnatzy et al. 2004).

The morphology of the Dufour's gland can vary between groups, but the structure is essentially a single layered epithelial tube. It is partially covered by a muscular layer and is associated with tracheoles and nerves (Hermann and Blum 1967a, 1967b, Landolt and Akre 1979, Downing and Jeanne 1983, Billen 1986a, 1986b, Abdalla and Cruz-Landim 2004, Abdalla et al. 1999). Since there is a single layer of glandular epithelium, the Dufour's gland is a "class I" epidermal gland, as described by Noirot and Quennedy (1974). The gland cells are abundant in smooth endoplasmic reticulum, secretory vesicles, mitochondria, and electron dense granules, consistent with their role in secretion (Billen 1982, 1986a, 1986b). The cells secrete material into the lumen of the gland, which is then carried outwards. Muscles located around the opening of the gland's duct may help in controlling the flow of secretion.

\section{Chemistry}

The Dufour's gland is believed to have evolved from the colleterial gland. Therefore in the ancestral state, the Dufour's gland secretions might be similar to colleterial gland 
secretions, found to be glucosides, proteins and enzymes in Lepidoptera and Blattodea, consistent with its role in reproduction (Pau et al. 1971, Sugumaran and Nellaiappan 1990, Jin et al. 2006). Unfortunately the chemistry of the colleterial gland/Dufour's gland in basal hymenopterans (Symphyta) and in many other non-aculeate hymenopterans remains unexplored. The Dufour's gland secretion has generally been found to contain long chain saturated and unsaturated hydrocarbons in most taxa that have been examined. In addition to hydrocarbons, various other volatile, semi-volatile and non-volatile compounds like terpenoids, alcohols, esters, long chain fatty acids, sugars, quinones, various aromatic compounds, traces of cholesterol and aldehydes have been reported. Fig. 2 lists the types of compounds that have been reported from different groups of hymenopterans.

It can be seen that secretion of long chain hydrocarbons is the most ubiquitous trait amongst all hymenopterans whose Dufour's gland chemistry has been analyzed (Fig. 2). Thus secretion of hydrocarbons is likely to be an ancestral trait common to all hymenopterans, while other categories of compounds that have been reported are likely to be derived traits. In Apoidea, Andrenidae, Colletidae and Halictidae are closely related clades that share esters with terpene derivatives (Hefetz et al. 1979, Duffield et al. 1981, Hefetz 1987). The Colletidae and Halictidae are sister clades that share macrocyclic lactones. The Megachilidae is sister to the Apidae and has triglycerides, a trait shared with Anthophorini, which is basal to other apids (Cane 1981, Cane and Carlson 1984, Kronenberg and Hefetz 1984, Cardinal et al. 2010). This trait is absent in other apids, who share esters as a common trait, suggesting that ester production may be a trait that evolved early during the diversification of the Apidae (Vinson et al. 1978, Duffield et al. 1984, Kronenberg and Hefetz 1984, Katzav-Gozansky et al. 1997, Abdalla et al. 2004, Amsalem et al. 2009). In the Vespoidea, again hydrocarbons are the trait common to most taxa, while the Formicidae show the presence of categories of compounds not found in other vespoids (see Fig. 2). Since the Formicidae show considerable adaptive radiation and occupy diverse ecological microhabitats, it is not surprising to see several derived traits with respect to Dufour's gland chemistry in the Formicidae. Hydrocarbons are likely to be the conserved trait in Dufour's gland chemicals of Hymenoptera, and different clades show appreciable differences in the composition of their Dufour's gland compounds, with the majority of clades presenting an admixture of ancestral and derived traits.

\section{Function}

The Hymenoptera form a basal sister clade with respect other insect orders like the Lepidoptera, Trichoptera, Siphonaptera and Diptera (Kristensen 1981, Whiting 2002, Kjer 2004). Since the Dufour's gland is believed to have evolved from the colleterial gland (an accessory reproductive gland) that is present in other insects (Carlet 1884, Maschwitz and Kloft 1971, Hermann 1969, Hermann and Blum 


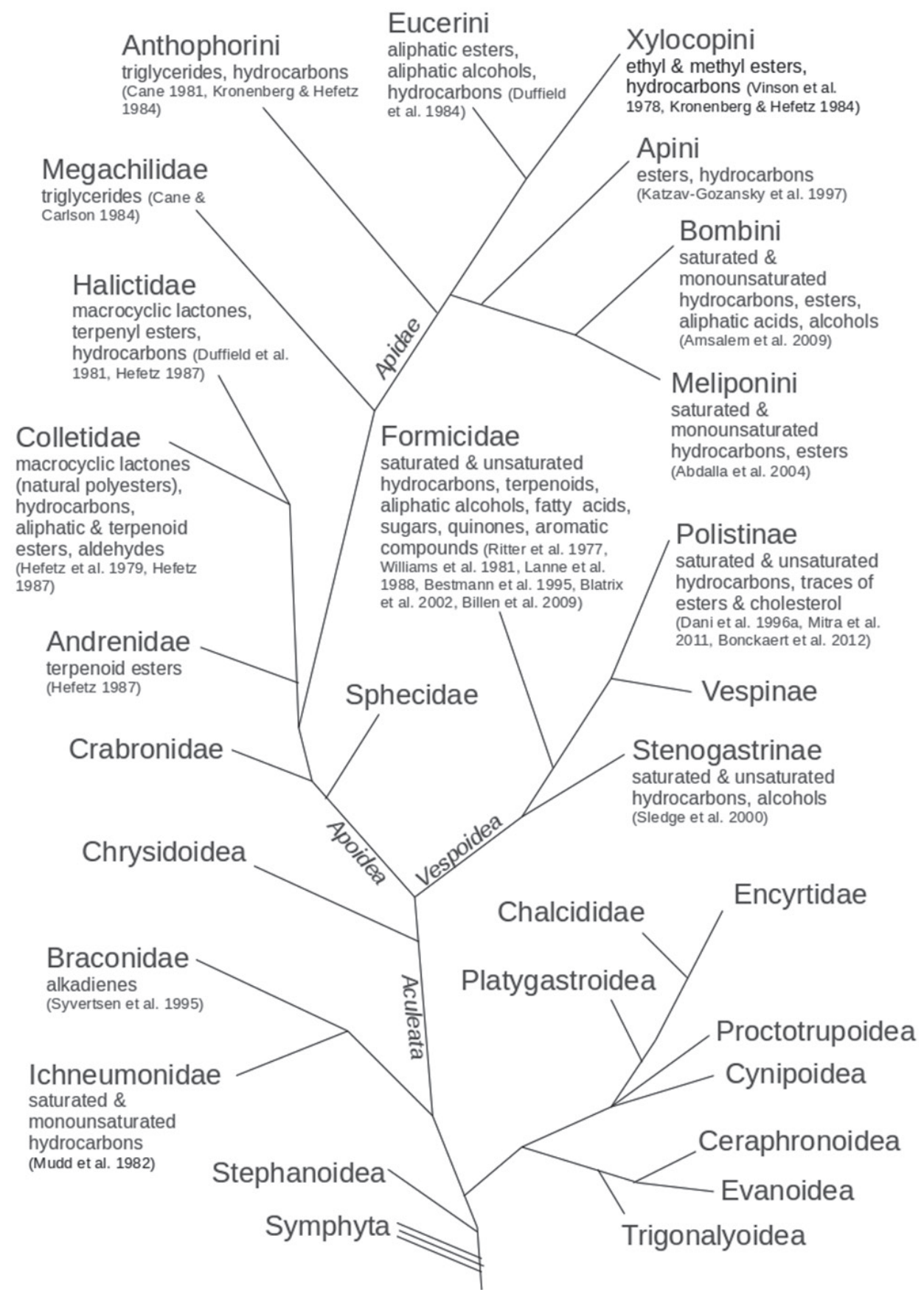

Figure 2. Diagram listing the categories of compounds reported from the Dufour's gland in various hymenopteran taxa, also showing the inter-relationships of the taxa. Dendrogram made following Brothers (1998), Schmitz and Moritz (1998), Whitfield and Cameron (1998), Grimaldi and Engel (2005), Brady et al. (2009), Vincent et al. (2010), and Cardinal et al. (2010). References cited in parenthesis below the names of compounds. Branch lengths do not have any significance. 
1967a, 1967b, 1981, Abdalla and Cruz-Landim 2001), the ancestral function of the gland could be similar to roles performed by the colleterial gland in other insects, like forming a protective casing (ootheca) over the eggs, or producing cementing material for attaching eggs to the substrate (Brunet et al. 1952). Colleterial glands in a moth (Lepidoptera, a sister clade of Hymenoptera) have been found to function in attaching eggs to leaves of plants (Chaudhuri and Sinha 1994). The colleterial gland in Symphyta has been reported as the homologue of the Dufour's gland (Robertson 1968, Van Marle and Piek 1986) but unfortunately, the function of this gland in symphytans (basal Hymenoptera) remains unexplored (Fig 3). With the exception of Orussidae, which is parasitic and basal to the apocritans, other symphytans are phytophagous, with Xyelidae being the clade basal to all other Hymenopetra (Davis et al. 2010). Perhaps the colleterial gland in Symphyta may be involved primarily in cementing eggs to plants, as in other phytophagous insects. In the older literature the Dufour's gland was often referred to as the "alkaline gland" and its secretions were assumed to be alkaline in nature in contrast to the poison gland, whose secretions were deemed acidic. It was often assumed that the general function of the Dufour's gland secretion is to lubricate the sting or ovipositor, lubricate passage of eggs during oviposition, glue eggs to the substratum, or to provide a protective coating to eggs, but experimental evidence for these postulated functions is absent (Dufour 1841, Billen 1987, Howard and Baker 2003, Gnatzy et al. 2004). The Dufour's gland is reported to serve various communicative purposes in social apocritans (Fig. 3).

Figure 3. Diagrammatic summary of the known functions of the Dufour's gland in various hymenopteran taxa, also showing the inter-relationships of the taxa. Dendrogram made following Brothers (1998), Schmitz and Moritz (1998), Whitfield and Cameron (1998), Grimaldi and Engel (2005), Brady et al. (2009), Vincent et al. (2010), and Cardinal et al. (2010). Figures in parenthesis beside each function denote references cited. Branch lengths do not have any significance.

References: 1 Rosi et al. (2001), 2 Mehrnejad and Copland (2007), 3 Vardal (2006), 4 Guillot et al. (1974), 5 Vinson and Guillot (1972), 6 Lawrence and Akin (1990), 7 Vinson (1978), 8 de Freitas et al. (2004), 9 Marris et al. (1996), 10 Huang et al. (2008), 11 Cane (1981), 12 Duffield et al. (1983), 13 Hefetz (1987), 14 Ayasse et al. (1990b), 15 Hefetz et al. (1979), 16 Albans et al. (1980), 17 Cane (1981), 18 Guedot et al. (2006), 19 Cane (1981), 20 Brooks and Cane (1984), 21 Ayasse et al. (1990a), 22 Smith et al. (1985), 23 Barrows (1975a), 24 Barrows et al. (1975b), 25 Ayasse et al. (1993), 26 Hefetz et al. (1986), 27 Hefetz (1987), 28 Smith and Wenzel (1988), 29 Cane and Carlson (1984), 30 Duffield et al. (1984), 31 Norden et al. (1980), 32 Hefetz et al. (1982), 33 Shimron et al. (1985), 34 Frankie and Vinson (1977), 35 Vinson et al. (1978), 36 Katzav-Gozansky et al. (2002), 37 Sole et al. (2002), 38 Oldroyd et al. (2002), 39 Katzav-Gozansky et al. (2007), 40 Malka et al. (2008), 41 Tengö et al. (1991), 42 Oldham et al. (1994), 43 Ayasse et al. (1999), 44 Amsalem et al. (2009), 45 Amsalem and Hefetz (2010), 46 Abdalla and Cruz-Landim (2004), 47 Downing and Jeanne (1983), 48 Downing (1991), 49 Dani et al. (1996a), 50 Dani et al. (1996b), 51 Mitra et al. (2011), 52 Mitra and Gadagkar (2011), 53 Mitra and Gadagkar (2012a), 54 Mitra and Gadagkar (2012b), 55 Jeanne (1977), 56 Reed (1982), 57 Reed and Akre (1982), 58 Barr-Nea et al. (1976), 59 Sledge et al. (2000), 60 Fortunato and Turillazzi (2012), 61 Turillazzi (1989), 62 Cervo et al. (2002), 63 Law et al. (1965), 64 Hölldobler and Wilson (1970), 65 Williams et 


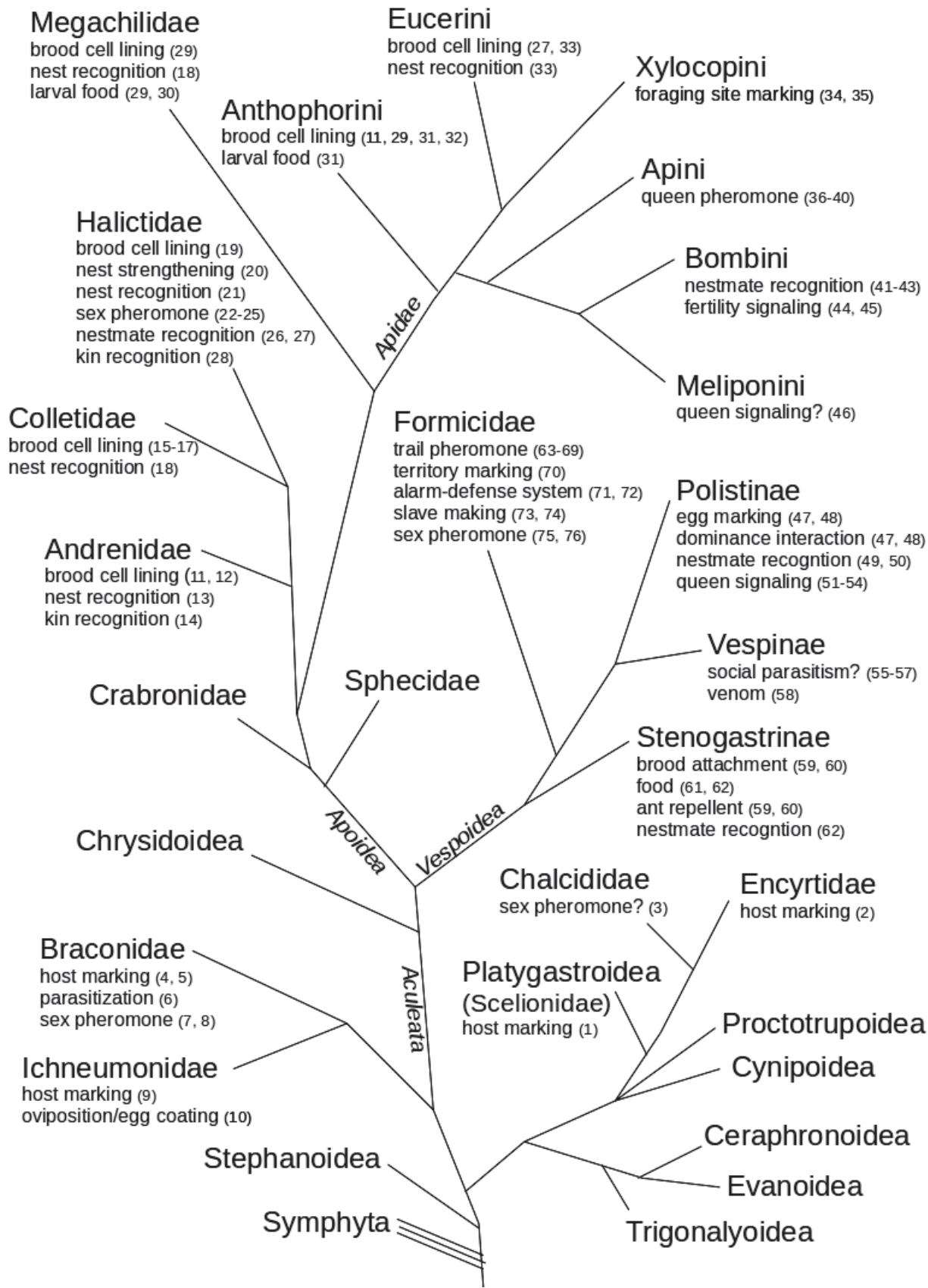

al. (1981), 66 Blatrix et al. (2002), 67 Jeanson et al. (2003), 68 Greene and Gordon (2007), 69 Morgan (2009), 70 Cammaerts et al. (1977), 71 Wilson and Regnier (1971), 72 Whitehouse and Jaffe (1996), 73 Topoff et al. (1988), 74 Mori et al. (2000), 75 Hölldobler and Wilson (1990), 76 Ayasse et al. (2001). 


\section{a) Parasitic wasps}

The evolution of the parasitic life history has been considered to be an important factor that led to the massive divergence and adaptive radiation of the Hymenoptera (Heraty et al. 2011). Unfortunately, the function of the Dufour's gland remains poorly explored in parasitic Hymenoptera that are basal to the more advanced groups of aculeates. Among various non-aculeate parasitic apocritans the function of the Dufour's gland may range from host marking (oviposition site marker), sex attractant, coating the egg surface or facilitating oviposition. In Chalcidoidea, the Dufour's gland region has been found to elicit a male courtship response in the chalcid wasps Brachymeria lasus and B. intermedia (Chalcididae) and thereby it has been proposed that Dufour's gland secretions may act as a sex pheromone (Simser and Coppel 1980). There is some evidence of Dufour's gland secretion acting as host marking chemicals in Psyllaephagus pistaciae (Encyrtidae) that can be used to avoid ovipositing in a parasitized host (Mehrnejad and Copland 2007). The function of Dufour's gland remains unexplored in fig wasps (Agaonidae). In Ichneumonoidea, Dufour's gland hydrocarbons have been implicated in host marking in Cardiochiles nigriceps and Micropletis croceipes (Braconidae) (Guillot et al. 1974, Vinson and Guillot 1972), and also in Nemeritis canescens and Itoplectis naranyae (Ichneumonidae) (Mudd et al. 1982, Hubbard et al. 1987, Ueno 1994). It has been found that not only may the Dufour's gland function in host marking in Venturia canescens (Ichneumonidae), but females may also discriminate between hosts parasitized by other closely related females versus those parasitized by unrelated females, thereby ensuring that their offspring do not have to compete with other genetically similar larvae in the same host (Marris et al. 1996). In Diadegma semiclausum (Ichneumonidae), Dufour's gland secretions have been reported to be added along with venom gland secretions to mature eggs that are ready to be laid (Huang et al. 2008). The Dufour's gland has been reported to act as a female sex pheromone in Cardiochiles nigriceps and Cotesia flavipes (Braconidae) (Vinson 1978, Syvertsen et al. 1995, de Freitas et al. 2004). In Biosteres longicaudatus (Braconidae), virus-like particles have been reported to accumulate in the Dufour's gland, which are injected into the host during parasitization, and may serve in suppressing the immune system of the host during development of parasitic larvae in the host's body (Lawrence and Akin 1990). In Platygastroidea, evidence for host marking has been found in Trissolcus basalis (Scelionidae) (Rosi et al. 2001).

The function of the Dufour's gland remains to be studied in Cephranoidea, Evanoidea, Megalyroidea, Mymarommatoidea, Proctotrupoidea, Stephanoidea, and Trigonaloidea, while recent evidence suggests that the Dufour's gland may be absent in Cynipoidea (Vardal 2006).

\section{b) Aculeata}

All social hymenopterans belong to the Aculeata, a clade which has received much attention over the years. Consequently, most of the information on the function of the 
Dufour's gland comes from aculeates. Aculeates are characterized by the development of the stinging apparatus, which leads to a separation of the sting from any oviposition related functions (Hunt 2007). In aculeates, the speculations regarding ancestral functions of the Dufour's gland include sting lubrication, venom constituent or role in oviposition (Dufour 1841, Billen 1987, Howard and Baker 2003, Gnatzy et al. 2004), but definitive demonstrations are lacking. Many studies have looked at the function of the Dufour's gland in the two well studied groups: the Apoidea and Vespoidea. Among solitary aculeates, the function of Dufour's gland remains unknown in the Chrysidoidea (cuckoo wasps). Since this group is basal to other aculeates, it would be of interest to investigate the role of the Dufour's gland in this group. Since the Chrysidoidea is comprised mostly of parasitoids, perhaps the role of the Dufour's gland here is similar to that in the parasitoid non-aculeates. The Dufour's gland probably underwent further modifications that were possible with the development of the stinging apparatus of the Aculeata, which removes any constraints related to oviposition from the stinging apparatus (Whitfield 1992), and thereby with the evolution of the sting, the Dufour's gland can be freed from prior evolutionary constraints. Indeed, structural modifications whereby the Dufour's gland no longer remains connected to the reproductive tract but opens instead into the sting has been documented (Billen 1987, Gnatzy et al. 2004). The function of the Dufour's gland in the Aculeata varies widely with variation in mode of living.

In Apoidea, the primary role of the Dufour's gland in various ground nesting bees appears to be producing the brood cell lining. Dufour's gland secretions have been found to be involved in forming a protective lining of the brood cells in various ground dwelling bees in Colletidae, Andrenidae, Halictidae, and some Apidae (Anthophorini and Eucerini), and sometimes they also form a hydrophobic lining for their pollen balls (Hefetz et al. 1979, Albans et al. 1980, Cane 1981, Duffield et al. 1981, 1983, Cane and Carlson 1984, Hefetz et al. 1982, 1986, Hefetz 1987). Ground dwelling bees face the challenge of keeping their larval food free from microbial growth, desiccation, and soaking by water. They have evolved to respond to this challenge by coating their brood cell with a hydrophobic lining that forms a sheath around the larval food. Secretions of the Dufour's gland have been found to be involved in forming this cell lining. Consequently the Dufour's gland has been found to become hypertrophied with the increase in activity during the nest construction phase (Lello 1971a, 1971b, Kronenberg and Hefetz 1984). Production of brood cell lining is an important adaptation for mass provisioners, ensuring that the food remains fresh and suitable for consumption by the larvae. Unfortunately, it is not known whether a similar function is served by the Dufour's gland in ground dwelling digger wasps, sand wasps and bee wolves (Sphecidae and Crabronidae), which utilize similar nest substrates. In the Crabronidae there is evidence for the post pharyngeal gland being involved in prey embalming, which may serve the same function as served by the protective hydrophobic cell lining of ground dwelling bees (Strohm et al. 2001). In the melittid bee Hesperapis the Dufour's glands are tiny and appear to be secondarily derived, as they are correlated with the absence of cell lining or with producing cell lining from 
exogenously derived substances (Cane 1983). In communally nesting mining bees of genus Andrena (Andrenidae), Dufour's gland compounds have been found to vary with genetic relatedness, thereby implying a possible role in kin recognition (Ayasse et al. 1990b). Such compounds have also been implicated in marking the nest entrance, helping in locating the nest within the nesting site (Hefetz 1987). In the sweat bee Lasioglossum malachurum (Halictidae), the pattern of Dufour's gland compounds was found to differ between virgin and mated queens, suggesting a possible involvement in mating and courtship (Ayasse et al. 1993). Mated queens had higher proportion of macrocyclic lactones (used in nest construction), and lower proportion of isopentyl esters (volatiles), as compared to virgin queens, and the composition of Dufour's gland compounds was found to change within one day of mating (Ayasse et al. 1993). In the same species, L. malachurum (Halictidae), the pattern of ester composition has also been found to differ between young virgin queens and old nesting queens, and the pattern has also been correlated with volume of fat body and status of ovarian development, implying possible involvement in sex pheromonal communication and in nest recognition (Ayasse et al. 1990a). Dufour's gland lactones have been found to act as a sex pheromone in L. zephyrum (Smith et al. 1985, Barrows 1975a, Barrows 1975b). Dufour's gland compounds have been implied in nestmate recognition and kin recognition as well in halictine bees (Hefetz et al. 1986, Hefetz 1987, Smith and Wenzel 1988, Soro et al. 2011). In Halictus hesperus (Halictidae) Dufour's gland secretion has been found to impart structural strength to the opening of the nest (Brooks and Cane 1984). In Eucera palestinae (Apidae: Eucerini), in addition to serving as a cell lining, Dufour's gland compounds also serve to mark the nest entrance and are used by individuals to locate their nest within dense nest aggregations (Shimron et al. 1985). A similar function has been proposed for Colletes cunicularius (Colletidae) and Osmia lignaria (Megachilidae) as well (Guédot et al. 2006). To serve as a semiochemical used in nest recognition, the Dufour's gland chemicals must show considerable inter-individual variability. Such variability has indeed been reported in some species (Kronenberg and Hefetz 1984, Hefetz 1987). In some Megachile species (leaf cutter bees) (Megachilidae), Dufour's gland compounds have been found mixed with larval food (bee bread), implying that they may serve as larval nutrition, or possibly to protect the larvae from fungal or bacterial attack (Cane and Carlson 1984, Duffield et al. 1984). Among short-tongued bees (Colletidae, Halictidae, Andrenidae and Melittidae) chemosystematic analysis suggests that Colletidae, Oxaeinae, Nomiinae and Halictinae comprise a monophyletic group (lactone producing bees), sharing macrocyclic lactones that are not found in any other hymenopterans. The other short-tongued bees (Andrenidae, Melittidae and Dufoureinae (currently Systrophinae)) form another monophyletic clade, sharing hydrocarbons (Cane 1983). The function of Dufour's gland in other solitary Apoidea like the Sphecidae (digger wasps), Crabronidae (sand wasps and bee wolves), and Ampulicidae (cockroach wasps) remains unexplored. Thus in addition to forming the cell lining, nest recognition seems to be another widespread function of Dufour's gland chemicals in bees. The same chemicals that are already in use for lining the nest surface can also be used by the organisms to identify their nests. 
Various communicative roles of the Dufour's gland like kin recognition and nestmate recognition are reported in communally nesting species of Andrenidae and Colletidae, and social Halictidae (Fig. 3).

In the Apidae, the role of the Dufour's gland in producing brood cell lining is found in ground dwelling bees of the genera Anthophora (Anthophorini) and Eucera (Eucerini) (Stephen and Torchio 1961, Norden et al. 1980, Cane and Carlson 1984, Shimron et al. 1985) and in ground dwelling carpenter bees as well (Xylocopa olivieri, Apidae: Xylocopini) (Kronenberg and Hefetz 1984). Xylocopines generally nest in wood (mostly tree trunks), and ground nesting strategy is an exception for this group. Thus the Dufour's gland secretions may have secondarily gained the function of producing brood cell lining in xylocopines. The function of the Dufour's gland in secreting a cell lining in the various ground nesting Apidae can be the result of the retention of a function present in ancestors of this group who diversified to form the different present day phyla. However, cases of convergent evolution owing to similarity in ecological habits cannot be ruled out. Similar to its suggested role in the Megachilidae, the role of the Dufour's gland in producing larval food has been demonstrated in Anthophora abrupta (Norden et al. 1980). In carpenter bees (Xylocopini), Dufour's gland has been implicated in foraging site marking, i.e. marking flowers that have been visited for pollen or nectar collection (Fig. 3). This marking is temporary and fades away over a short period of time, over which the flower is able to replenish its nectar. In Xylocopa virginica (Xylocopini) Dufour's gland secretions are deposited on flowers visited by bees, and serves to deter visits by conspecifics on a short term (Frankie and Vinson 1977, Vinson et al. 1978). In kleptoparasitic Nomadini, male mandibular gland secretion has been found to mimic the Dufour's gland secretion of their hosts. Males have been found to coat females with their mandibular gland secretion, which renders the chemical profile of the female similar to the cell lining of their host, thereby facilitating kleptoparasitism (Tengö and Bergström 1977).

Among the corbiculate apids (Apini, Bombini, Meliponini and Euglossini), communicative functions for the Dufour's gland secretions have been reported in various taxa. In bumble bees (Bombini), the Dufour's gland has been found to increase in size and activity with the reproductive activity and age of queens, and queen worker differences in gland size have also been reported, implying a possible role as an egg marking pheromone (Abdalla et al. 1999). Queen signaling and nestmate recognition through Dufour's gland has also been implied (Tengö et al. 1991, Oldham et al. 1994, Ayasse et al. 1999). In Bombus terrestris it has been found that workers may advertise their sterility through esters secreted in their Dufour's gland, and thereby avoid being policed by queens or other egg laying workers. These esters disappear when an individual starts to develop ovaries (Amsalem et al. 2009, Amsalem and Hefetz 2010). Cuckoo bumblebees (subgenus psithyrus) can be attracted by the Dufour's gland odors of their hosts (other Bombus) to parasitize them (Fisher et al. 1993). In stingless bees (Meliponini) it has been found that reproductively active queens may have larger Dufour's glands than virgin queens and the gland may be absent in workers; however the function remains unknown and has been speculated as involvement in reproduction or in queen 
signaling, and it has been suggested that the Dufour's gland secretions may act as a queen pheromone, as virgin queens have hydrocarbons in their Dufour's gland, while mated physogastric queens have esters in addition to hydrocarbons (Abdalla and CruzLandim 2004, Abdalla et al. 2004). In honey bees (Apini), there are multiple evidences for Dufour's gland esters functioning in pheromonal queen signaling. Such esters are initially absent in workers, but start being secreted in egg laying workers (KatzavGozansky et al. 2002, Oldroyd et al. 2002, Katzav-Gozansky et al. 2007, Malka et al. 2008). It has been proposed that multiple mating of queens triggers the production of esters from the Dufour's gland (Richard et al. 2011), while in the case of workers it is probably triggered by the absence of queen pheromone. The egg laying workers of Apis mellifera capensis, who act as social parasites of A. mellifera scutellata, produce Dufour's gland secretions that have been found to mimic the queen gland secretion better than that of egg laying $A$. m. scutellata workers, thereby increasing the efficiency of their social parasitism (Sole et al. 2002). The role of Dufour's gland in Euglossini remains unknown. Thus in honey bees (Apini), bumble bees (Bombini), and stingless bees (Meliponini) the Dufour's gland serves communicative functions like fertility signaling (queen pheromone) and nestmate recognition (Fig. 3).

The Vespoidea contains two major groups of social Hymenoptera: the Formicidae and Vespidae. Apart from these two families, the function of Dufour's gland remains unexplored in other Vespoidea (Tiphiidae, Sapygidae, Mutillidae, Pompilidae, Rhopalosomatidae, Scoliidae, and Sierolomorphidae). In ants (Formicidae), Dufour's gland secretions have often been found to act as a trail pheromone in Formicinae and Ponerinae (Law et al. 1965, Hölldobler and Wilson 1970, Williams et al. 1981, Bestmann et al. 1995, Blatrix et al. 2002, Jeanson et al. 2003). They have a recruitment effect, serve in territorial marking, or in setting foraging direction (Cammaerts et al. 1977, Greene and Gordon 2007). Often the Dufour's gland acts in unison with other glands, like the poison gland, in communicating recruitment signals for recruitment of workers to food or nesting sites. Secretions of the Dufour's gland are often applied on the substrate by extruding the sting and dragging it (Hölldobler and Wilson 1970, Morgan 2009). However, other glandular sources of trail pheromone originating in the metasoma (hindgut, pygidial gland, post-pygidial gland) or legs (tibial glands, footprint glands on the hind pre-tarsi) are also known (Morgan 2009). The Dufour's gland secretion can have colony specificity and species specificity, thereby ensuring fidelity of the trail (Traniello 1980, Haak et al. 1996). The Dufour's gland has also been implicated as a storage site for chemicals involved in the alarm-defense system of ants, whereby the same chemicals can produce an alarm reaction among nestmates, while simultaneously acting as repellents to intruders (Wilson and Regnier 1971, Whitehouse and Jaffe 1996). In slave making ants of the genus Polygerus Dufour's gland chemicals have been found to be used in manipulating the behavior of the host species. Dufour's gland compounds facilitate the new queen of the slave making ant to invade a host colony, and reduce any aggression shown by the host workers towards the usurper (Topoff et al. 1988, Mori et al. 2000). Such compounds may also act as a repellent and thereby facilitate usurpation of a host colony (Ruano et al. 2005). Another function of 
Dufour's gland in slave making ants is to act as a source of propaganda substances that elicit panic among defending host workers, thereby increasing the efficiency of slave capturing raids (Brandt et al. 2006). Dufour's gland compounds have also been found to act as sex pheromones, and can also be involved in the calling behavior exhibited by females, whereby virgin gynes place themselves in strategic positions outside their nests and "call" for mates by releasing sex pheromones (Hölldobler and Wust 1973, Hölldobler and Wilson 1990, Ayasse et al. 2001).

In the hover wasps (Vespidae: Stenogastrinae) the Dufour's gland substances act as a substrate on which eggs are laid and food is placed for subsequent consumption by larvae and adults (Sledge et al. 2000, Fortunato and Turillazzi 2012). The secretion of a jelly-like substance by the Dufour's gland that functions in larval nutrition has been proposed as an important step towards the evolution of sociality in this lineage. It enables anchoring eggs and larvae, and the storage of liquid food in the nest, subsequently facilitating the evolution of behavioral mechanisms that facilitate social interaction (Turillazzi 1989, Cervo et al. 2002). Apart from these functions, Dufour's gland secretions also serve as ant repellents. They are used to construct sticky barriers which serve as ant guards around the nest (Sledge et al. 2000, Fortunato and Turillazzi 2012). These aid in preventing predation of immature brood by ants. Dufour's gland compounds may also function in nestmate recognition (Cervo et al. 2002). Additionally, the Dufour's gland secretions serve as food for both larvae and adults and can be stored for future consumption. This seems to be an important development that may have facilitated the evolution of sociality in this group (Turillazzi 1989, Cervo et al. 2002, Fortunato and Turillazzi 2012). The Dufour's gland secretions function as ant repellants (Sledge et al. 2000), and this should be another important factor facilitating progressive provisioning of brood. Progressive provisioning of brood is a character shared by most eusocial Hymenoptera, and is important for the evolution of sociality (Hunt 2007). Evidence for Dufour's gland compounds acting in nestmate recognition in stenogastrines reinforces the idea of chemicals having other primary functions being secondarily involved in chemical communication. Since the gland secretions have to be applied inside cells, and also outside and around the nest, to repel ants, this should facilitate nest or nestmate recognition by nest odor. Thus the Dufour's gland secretions can be intertwined with the coevolution of brood rearing, avoiding brood predation, and maintaining colony fidelity, and appear to have an important role in the evolution of sociality in hover wasps.

Among other vespids, in the Vespinae the Dufour's gland has been postulated to facilitate social parasitism by increasing acceptance of parasites among host individuals, or by acting as an alarm pheromone, eventually serving as a means of usurping and controlling the host colony (Jeanne 1977, Reed 1982, Reed and Akre 1982). The Dufour's gland secretion of Vespa orientalis has been reported to be slightly lethal to honey bees, thereby implicating a role in venom secretion (Barr-Nea et al. 1976). This may be another example of an adaptation of Dufour's gland secretions for a function not reported in other hymenopteran taxa. In Polistinae, Dufour's gland compounds have been implicated in dominance interactions, egg marking, nestmate recognition, 
and queen signaling (Downing and Jeanne 1983, Downing 1991, Dani et al. 1996a, 1996b, Mitra et al. 2011, Mitra and Gadagkar 2011, Mitra and Gadagkar 2012a, 2012b). In the polistine wasp Ropalidia marginata the Dufour's gland has been shown to be involved in producing the queen pheromone, using which the queen conveys her presence to workers and thereby maintains reproductive monopoly (Mitra et al. 2011). It has also been found that the Dufour's gland hydrocarbon composition varies as a function of ovarian development, thereby suggesting that such chemicals can act as an honest signal of the queen's fertility (Mitra and Gadagkar 2011, Mitra and Gadagkar 2012a, 2012b). Interestingly it has been found that the cuticle and the haemolymph of $R$. marginata also contain the same set of hydrocarbons as found in the Dufour's gland, thereby implying that these hydrocarbons can be synthesized in the oenocytes of fat bodies, from where they enter circulation in the haemoplymph and are finally sequestered and stored in the Dufour's gland or secreted on the cuticle (Mitra and Gadagkar: in press). The function of the Dufour's gland remains unexplored in other Vespidae like potter wasps (Eumeninae) or pollen wasps (Masarinae). Examples of chemical communication through Dufour's gland in vespids, like dominance signaling, queen signaling, nestmate recognition or social parasitism (Fig. 3), again suggest adaptations in a case specific manner. The ability to perceive chemicals secreted from the Dufour's gland should be necessary to facilitate the evolution of adaptive communicative functions. Interestingly, in a polistine wasp it was found that dominance signaling through Dufour's gland secretions may act via egg marking (Downing and Jeanne 1983, Downing 1991), perhaps exemplifying the ancestral function of egg coating giving rise to novel communicative roles. The role of the Dufour's gland in communication in vespids may have coevolved with the evolution of various behavioral and chemical communication systems exhibited by vespids, or it may also have evolved coincidentally with the evolution of vespid sociality.

\section{Concluding remarks}

It can be seen that the Dufour's gland secretion has undergone a variety of shifts in its functionality in various hymenopteran lineages. The ancestral function related to egg coating and attachment of eggs to the substrate might be retained (or perhaps secondarily gained) only in stenogastrines, in addition to a few extant clades like ichneumonids and perhaps a few polistines (Fig. 3). In parasitic wasps, it has gained the function of host marking, which may be the most widespread function of the Dufour's gland in non-aculeates (Fig. 3). Dufour's gland secretions form a chemical mark on the host body, which can be used by the parasites as a recognition cue, thereby preventing overinfection of the same host. In these groups, the ovipositor is long, sting-like, and the precursor of the sting of Aculeata, and thereby secretions of the Dufour's gland (perhaps involved in oviposition and other reproductive functions) can get co-opted to be used as semiochemicals used to avoid oviposition in a host that is already parasitized. This is particularly interesting from the perspective of evolution of semiochemicals, be- 
cause chemicals that already exist for other purposes often get co-opted later for being used as a signal (Stoka 1999). Since the Dufour's gland chemicals may be involved in oviposition, they will inadvertently get deposited on the host when the parasite injects her eggs. With the evolution of the signaling system, which requires developing the ability to detect these chemicals, these chemicals can advertise the unavailability of a host to other potential parasites. The Dufour's gland secretions have also been reported to act as sex pheromone in braconids (Fig. 3). Unsaturated hydrocarbons have been reported in Dufour's gland secretions of braconids and ichneumonids (Fig. 2), and it is possible that the ability to secrete such semi-volatile compounds is a necessary prerequisite for evolving the function of sex pheromones or other semiochemicals that are detected at a distance. The presumed ancestral role of involvement in oviposition or egg coating appears to have been retained in ichneumonids (Huang et al. 2008), but it may well be that such a role is present in other taxa as well, awaiting discovery.

In some non-apid bees (Colletidae and Halictidae), the gland has primarily acquired the role of producing cell linings, which are essential for preserving provisions for the brood. This clearly has arisen in response to the challenges faced for keeping food unattended and unspoiled in cells constructed in the soil, where food is always prone to becoming over-hydrated and being attacked by microbes. The chemistry of Dufour's gland secretions have been altered accordingly in these two groups of ground nesting bees and consist of terpenoid esters and other esters, and macrocyclic lactones in addition to hydrocarbons (Fig. 2). These chemicals often form a natural polyester lining inside the brood cells, acting as an effective water repellent. It is possible that this function of producing the brood cell lining from Dufour's gland secretions may have arisen simultaneously with diversification of the ground nesting bees into their present state. Interestingly, there are also ground nesting basal melittids and megachilids that do not line their cell walls (Cane 1983). Hence it is possible that this trait has arisen independently multiple times. The function of producing cell lining from Dufour's gland secretions is again found in ground nesting apid bees (Anthophorini and Eucerini), although the chemistry of the secretions is different, comprising of hydrocarbons and esters (Fig. 2). The function of producing brood cell lining is lost in social bees of Apini, Bombini and Meliponini, where communicative functions take precedence, and unsaturated hydrocarbons and esters seem to be involved in this function. Members of Apini, Bombini and Meliponini generally construct their nests from wax produced from abdominal wax glands (cuticular exocrine glands), sometimes also using cellulose and other material collected from their surroundings in the nest construction process. Hence it is not surprising to find that the Dufour's gland no longer plays a role in lining their cells or producing material for nest construction. Communicative roles are also seen in other social bees like the Halictidae, and in various vespoids. The Dufour's gland may have played an important part in the evolution of sociality in stenogastrines, as the conditions necessary for successful social living would have to be fulfilled in other ways in the absence of the Dufour's gland. The ancestral function of attachment of eggs to the substrate through Dufour's gland secretions may also have been retained in stenogastrines (however secondary gain of such function cannot be ruled out). The Dufour's gland plays communicative roles in polistines as well, emphasiz- 
ing the utility for developing modes of chemical communication in conjunction with the evolution of social life. In the Formicidae there is enormous variation in the communicative roles played by the Dufour's gland, concomitant with the wide ranging adaptive radiation and speciation undergone by this group. The Formicidae show appreciable variation in communicative roles of the Dufour's gland ranging from trail pheromone and territory marking to alarm-defense, slave making, and serving as sex pheromones (Fig. 3). The role of the gland in trail formation has been demonstrated in many trail forming species. The ability of the ants to perceive Dufour's gland chemicals should be a prerequisite for involvement of such chemicals in trail marking. Accordingly the chemical composition of the Dufour's gland also includes various volatile and semi-volatile compounds like unsaturated hydrocarbons, terpenoids, alcohols, acids, quinones and aromatic compounds. The involvement of the Dufour's gland in the alarm-defense system or in slave making, may be secondary adaptations. Perhaps the involvement of Dufour's gland chemicals as an alarm pheromone has been exploited by slave making species to give rise to this special kind of social parasitism. The involvement of the Dufour's gland in sex pheromone production in ants is reminiscent of a similar role in non-aculeate hymenopterans.

Thus the Dufour's gland secretions display a fair degree of functional plasticity, in conjunction with the diversity of ecological habits followed by different groups of Hymenoptera (Fig. 3). The basic function of the gland in all Hymenoptera remains the secretion of chemicals, but the nature of secretions and the function of the secreted chemicals have undergone appreciable modification in various taxa. This illustrates how an organ can evolve to give rise to various functions in response to challenges posed by the way of life followed by a lineage. The function of the Dufour's gland remains unexplored in various basal Hymenoptera, especially the Symphyta. Future explorations in that direction should be able to provide a clearer picture of the role of the gland in the ancestral condition. This will result in a comprehensive view of the evolution of Dufour's gland function in the Hymenoptera.

\section{Acknowledgements}

I thank Dr. John L. Neff (editor) and Dr. Robin M. Crewe (reviewer) for their helpful comments on earlier versions of this manuscript.

\section{References}

Abdalla FC, Cruz-Landim C da (2001) Dufour's glands in Hymenopterans (Apidae, Formicidae, Vespidae): a review. Revista Brasileira de Biologia 61: 95-106. doi: 10.1590/S003471082001000100013

Abdalla FC, Cruz-Landim C da (2004) Occurrence, morphology and ultrastructure of the Dufour gland in Melipona bicolor Lepeletier (Hymenoptera, Meliponini). Revista Brasileira de Entomologia 48: 9-19. doi: 10.1590/S0085-56262004000100002 
Abdalla FC, Jones GR, Morgan D, Cruz-Landim C da (2004) Chemical composition of the Dufour gland secretion in queens of Melipona bicolor (Hymenoptera, Meliponini). Journal of the Brazilian Chemical Society 15: 621-625. doi: 10.1590/S0103-50532004000500002

Abdalla FC, Velthius H, Cruz-Landim C da, Duchateau MJ (1999) Changes in the morphology and ultrastructure of the Dufour's gland during the life cycle of the bumble bee queen, Bombus terrestris (Hymenoptera: Bombini). Netherlands Journal of Zoology 49: 251-261. doi: 10.1163/156854299X00173

Albans KR, Aplin RT, Brehcist J, Moore JF, O’Toole C (1980) Dufour's gland and its role in secretion of nest cell lining in bees of the genus Colletes (Hymenoptera: Colletidae). Journal of Chemical Ecology 6: 549-564. doi: 10.1007/BF00987667

Amsalem E, Hefetz A (2010) The appeasement effect of sterility signaling in dominance contests among Bombus terrestris workers. Behavioral Ecology and Sociobiology 64: 1685-1694. doi: 10.1007/s00265-010-0982-4

Amsalem E, Twele R, Francke W, Hefetz A (2009) Reproductive competetion in the bumblebee Bombus terrestris: do workers advertise sterility? Proceedings of the Royal Society of London B 276: 1295-1304. doi: 10.1098/rspb.2008.1688

Ayasse M, Birnbaum J, Tengö J, van Doorn A, Taghizadeh T, Francke W (1999) Caste and colony specific chemical signals on eggs of the bumble bee, Bombus terrestris L. (Hymenoptera: Apidae). Chemoecology 9: 119-126. doi: 10.1007/s000490050042

Ayasse M, Engels W, Hefetz A, Lübke G, Francke W (1990a) Ontogenetic patterns in amounts and proportions of Dufour's gland volatile secretions in virgin and nesting queens of Lasioglossum malachurum (Hymenoptera: Halictidae). Zeitschrift für Naturforschung, C. 45: 709-714.

Ayasse M, Engels W, Hefetz A, Tengö J, Lübke G, Francke W (1993) Ontogenetic patterns of volatiles identified in Dufour's gland extracts from queens and workers of the primitively eusocial halictine bee, Lasioglossum malachmum (Hymenoptera: Halictidae). Insectes Sociaux 40: 41-58. doi: 10.1007/BF01338831

Ayasse M, Leys R, Pamilo P, Tengö J (1990b) Kinship in communally nesting Andrena (Hymenoptera; Andrenidae) bees is indicated by composition of Dufour's gland secretions. Biochemical Systematics and Ecology 18: 453-460. doi: 10.1016/0305-1978(90)90092-T

Ayasse M, Paxton RJ, Tengö J (2001) Mating behavior and chemical communication in the order Hymenoptera. Annual Review of Entomology 46: 31-78. doi: 10.1146/annurev. ento.46.1.31

Baker J, Howard R, Morrill W, Meers S, Weaver D (2005) Acetate esters of saturated and unsaturated alcohols (C12-C20) are major components in Dufour glands of Bracon cephi and Bracon lissogaster (Hymenoptera: Braconidae), parasitoids of the wheat stem sawfly, Cephus cinctus (Hymenoptera: Cephidae). Biochemical Systematics and Ecology 33: 757-769. doi: 10.1016/j.bse.2004.12.025

Barr-Nea L, Rosenberg P, Ishay J (1976) The venom apparatus of Vespa orientalis: morphology and cytology. Toxicon 14: 65-68. doi: 10.1016/0041-0101(76)90121-5

Barrows EM (1975a) Individually distinctive odors in an invertebrate. Behavioral Biology 15: 57-64. doi: 10.1016/S0091-6773(75)92079-9

Barrows EM (1975b) Mating behaviour in halictine bees. III. Copulatory behaviour and olfactory communication. Insectes Sociaux 22: 307-331. doi: 10.1007/BF02223079 
Bestmann HJ, Janssen E, Kern F, Liepold B, Hölldobler B, Boveri T (1995) All-trans geranyl geranyl acetate and geranylgeraniol, recruitment pheromone components in the Dufour gland of the ponerine ant Ectatomma ruidum Pheromones, 100 [1]. Naturwissenschaften 82: 334-336. doi: 10.1007/BF01131530

Billen J (1986a) Morphology and ultrastructure of the Dufour's and venom gland in the ant, Myrmica rubra (L.) (Hymenoptera: Formicidae). International Journal of Insect Morphology and Embryology 15: 13-25. doi: 10.1016/0020-7322(86)90003-6

Billen J, Morgan DE, Drijfhout F, Farnier K (2009) Unusual structural and chemical characteristics of the Dufour gland in the ant Meranoplus diversus. Physiological Entomology 34: 93-97. doi: 10.1111/j.1365-3032.2008.00659.x

Billen JPJ (1982) The Dufour gland closing apparatus in Formica sanguinea Latreille (Hymenoptera, Formicidae). Zoomorphology 99: 235-244. doi: 10.1007/BF00312297

Billen JPJ (1986b) Comparative morphology and ultrastructure of the Dufour gland in ants (Hymenoptera: Formicidae). Entomologia Generalis 11: 165-181.

Billen JPJ (1987) New structural aspects of the Dufour's and venom glands in social insects. Naturwissenschaften 74: 340-341. doi: 10.1007/BF00367931

Blatrix R, Schulz C, Jaisson P, Francke W, Hefetz A (2002) Trail pheromone of ponerine ant Gnamptogenys striatula: 4-methylgeranyl esters from Dufour's gland. Journal of Chemical Ecology 28: 2557-2567. doi: 10.1023/A:1021444321238

Bonckaert W, Drijfout FP, D'Ettorre P, Billen J, Wenseelers T (2012) Hydrocarbon signatures of egg maternity, caste membership and reproductive status in the common wasp. Journal of Chemical Ecology 38: 42-51. doi: 10.1007/s10886-011-0055-9

Brady SG, Larkin L, Danforth BN (2009) Bees, ants, and stinging wasps (Aculeata). In: Hedges SB, Kumar S (Eds) The timetree of life. Oxford University Press, 264-269.

Brandt M, Heinze J, Schmitt T, Foitzik S (2006) Convergent evolution of the Dufour's gland secretion as a propaganda substance in the slave making ant genera Protomognathus and Harpagoxenus. Insectes Sociaux 53: 291-299. doi: 10.1007/s00040-006-0871-z

Brooks RW, Cane JH (1984) Origin and chemistry of the secreted nest entrance lining of Halictus hesperus (Hymenoptera: Apoidae). Journal of Kansas Entomological Society 7: 161-165.

Brothers DJ (1998) Phylogeny and evolution of wasps, ants and bees (Hymenoptera, Chrysidoidea, Vespoidea and Apoidea). Zoologica Scripta 28: 233-250. doi: 10.1046/j.14636409.1999.00003.x

Brunet PCJ (1952) The formation of the ootheca by Periplaneta americana II the structure and function of the left colleterial gland. Quarterly Journal of Microscopical Science 93: 47-69.

Cammaerts MC, Morgan ED, Tyler R (1977) Territorial marking in the ant Myrmica rubra L. (Formicidae). Biology of Behaviour 2: 263-272.

Cane JH (1981) Dufour's gland secretion in the cell lining of bees (Hymenoptera: Apoidea). Journal of Chemical Ecology 7: 403-410. doi: 10.1007/BF00995762

Cane JH (1983) Preliminary chemosystematics of the Andrenidae and exocrine lipid evolution of the short-tongued bees (Hymenoptera: Apoidea). Systematic Zoology 32: 417-430. doi: $10.2307 / 2413168$ 
Cane JH, Carlson RG (1984) Dufour's gland triglycerides from Anthophora, Emphoropsis (Anthophoridae) and Megachile (Megachilidae) bees (Hymenoptera: Apoidea). Comparative Biochemistry and Physiology B 78: 769-772. doi: 10.1016/0305-0491(84)90132-9

Cardinal S, Straka J, Danforth B (2010) Comprehensive phylogeny of apid bees reveals the evolutionary origins and antiquity of cleptoparasitism. Proceedings of the National Academy of Sciences USA 107: 16207-16211. doi: 10.1073/pnas.1006299107

Carlet G (1884) Sur le venin des Hyménopteres et ses organes sécréteurs. C R Academy of Science, Paris 98, 1550-1551.

Cervo R, Dani FR, Zanetti P, Massolo A, Turillazzi S (2002) Chemical nestmate recognition in a stenogastrine wasp, Liostenogaster flavolineata (Hymenoptera Vespidae). Ethology Ecology and Evolution 14: 351-363. doi: 10.1080/08927014.2002.9522736

Chaudhuri A, Sinha AK (1994) Colleterectomy and its impact on some reproductive behaviour of the tropical Tasar silk moth, Antheraea mylitta Drury (Lepidoptera: Saturniidae). Invertebrate Reproduction and Development 26: 145-152. doi: 10.1080/07924259.1994.9672411

Dani FR, Morgan ED, Turillazzi S (1996a) Dufour gland secretion of Polistes wasp: chemical composition and possible involvement in nestmate recognition (Hymenoptera: Vespidae). Journal of Insect Physiology 42: 541-548. doi: 10.1016/0022-1910(95)00136-0

Dani FR, Fratini S, Turillazzi S (1996b) Behavioural evidence for the involvement of Dufour's gland secretion in nestmate recognition in the social wasp Polistes dominulus (Hymenoptera: Vespidae). Behavioral Ecology and Sociobiology 38: 311-319. doi: $10.1007 / \mathrm{s} 002650050247$

Davis RB, Baldauf SL, Mayhew PJ (2010) The origins of species richness in the Hymenoptera: insights from a family-level supertree. BMC Evolutionary Biology 10: 109. doi: 10.1186/1471-2148-10-109

de Freitas MDRT, MendonÇa ADL, Nascimento RRD, Sant'Ana AEG (2004) Behavioural evidence for a female sex pheromone in Cotesia flavipes (Hymenoptera: Braconidae). Physiological Entomology 29: 183-187. doi: 10.1111/j.0307-6962.2004.0385.x

Downing HA (1991) A role of the Dufour's gland in the dominance interactions of the paper wasp, Polistes fuscatus (Hymenoptera: Vespidae). Journal of lnsect Behavior 4: 557-565. doi: 10.1007/BF01048070

Downing HA, Jeanne RL (1983) Correlation of season and dominance status with activity of exocrine glands in Polistes fuscatus (Hymenoptera: Vespidae). Journal of the Kansas Entomological Society 56: 387-397.

D'Rozario AM (1942) On the development and homologies of the genitalia and their ducts in Hymenoptera. Transactions of the Royal Entomological Society, London 92: 363-415. doi: 10.1111/j.1365-2311.1942.tb01211.x

Duffield KM, Fernandes A, Lamb C, Wheeler JW, Eickwort GC (1981) Macrocyclic lactones and isopentenyl esters in the Dufour's gland secretion of halictine bees (Hymenoptera: Halictidae). Journal of Chemical Ecology 7: 319-331. doi: 10.1007/BF00995755

Duffield RM, Harrison SE, Maglott D, Ayorinde FO, Wheeler JW (1983) Exocrine secretion of bees. V. Terpenoid esters in the Dufour's gland secretions of Panurginus bees (Hymenoptera: Adrenidae). J Chem Ecol 9: 277-283. doi: 10.1007/BF00988045 
Duffield RM, Wheeler JW, Eickwort GC (1984) Sociochemicals of bees. In: Bell WJ, Cared RT (Eds) Chemical Ecology of lnsects. Chapman and Hall, London, 387-328.

Dufour L (1841) Recherches anatomiques et physiologiques sur les Orthoptères, les Hyménoptères et les Neuroptères. Mémoires de l'Académie des Sciences, Institute de France. Vol 7: 265-647.

Eller FJ, Bartelt RJ, Jones RL, Kulman HM (1984) Ethyl (Z)-9-hexadecenoate a sex pheromone of Syndipnus rubiginosus, a sawfly parasitoid. Journal of Chemical Ecology 10: 291-300. doi: $10.1007 / \mathrm{BF} 00987857$

Fisher RM, Greenwood DR, Shaw GJ (1993) Host recognition and the study of a chemical basis for attraction by cuckoo bumble bees (Hymenoptera: Apidae). Journal of Chemical Ecology 19: 771-786. doi: 10.1007/BF00985008

Fortunato A, Turillazzi S (2012) Dufour's gland possible role in the evolution of sting morphology and function in hover wasps (Hymenoptera Stenogastrinae). Arthropod Structure and Development 41: 259-264. doi: 10.1016/j.asd.2012.02.007

Frankie GW, Vinson SB (1977) Scent marking of passion flowers in Texas by female Xylocopa virginica texana (Hymenoptera: Anthophoridae). Journal of Kansas Entomological Society 50: 613-625.

Gnatzy W, Volknandt W, Schulz S (2004) Dufour gland of the digger wasp Liris niger: structure and developmental and biochemical aspects. Cell and Tissue Research 315: 125-138. doi: 10.1007/s00441-003-0813-2

Greene MJ, Gordon DM (2007) How patrollers set foraging direction in harvester ants. The American Naturalist 170: 943-948. doi: 10.1086/522843

Grimaldi D, Engel MS (2005) Evolution of the insects. Cambridge University Press.

Guédot C, Pitts-Singer TL, Buckner JS, Bosch J, Kemp WP (2006) Olfactory cues and nest recognition in the solitary bee Osmia lignaria. Physiological Entomology Volume 31: 110-119. doi: 10.1111/j.1365-3032.2005.00490.x

Guillot FS, Joiner RL, Vinson SB (1974) Host discrimination: isolation of hydrocarbons from the Dufour's gland of a braconid parasitoid. Annals of the Entomological Society of America 67: 720-21.

Haak U, Hölldobler B, Bestmann HJ, Kern F (1996) Species-specificity in trail pheromones and Dufour's gland contents of Camponotus atriceps and C. floridanus (Hymenoptera: Formicidae). Chemoecology 7: 85-93. doi: 10.1007/BF01239485

Hefetz A (1987) The role of Dufour's gland secretion in bees. Physiological Entomology 12: 243-253. doi: 10.1111/j.1365-3032.1987.tb00749.x

Hefetz A, Bergstrom G, Tengö J (1986) Species, individual and kin specific blends in Dufour's gland secretion of halictine bees: chemical evidence. Journal of Chemical Ecology 12: 197-208. doi: 10.1007/BF01045603

Hefetz A, Eickwort GC, Blum MS, Cane J, Bohart GE (1982) A comparative study of the exocrine products of cleptoparasitic bees (Holcopasites) and their hosts (Calliopsis) (Hymenoptera: Anthophoridae, Andrenidae). Journal of Chemical Ecology 8: 1389-1397. doi: 10.1007/BF01403102

Hefetz A, Fales HM, Batra SWT (1979) Natural polyesters: Dufour's gland macrocyclic lactones in the brood cell laminesters in Colletes bees. Science 204: 415-417. doi: 10.1126/ science.204.4391.415 
Hefetz A, Bergström G, Tengö J (1986) Species, individual and kin specific blends in Dufour's gland secretions of halictine bees chemical evidence. Journal of Chemical Ecology 12: 197-208. doi: 10.1007/BF01045603

Heraty J, Ronquist F, Carpenter JM, Hawks D, Schulmeister S, Dowling AP, Murray D, Munro J, Wheeler WC, Schiff N, Sharkey M (2011) Evolution of the hymenopteran megaradiation. Molecular Phylogenetics and Evolution 60: 73-88. doi: 10.1016/j. ympev.2011.04.003

Hermann HR (1969) The hymenoptera poison apparatus: evolutionary trends in three closely related subfamilies of ants (Hymenoptera: Formicidae). Georgia Entomological Society 4: 123-141. http://hdl.handle.net/10199/1584

Hermann HR, Blum MS (1967a) The morphology and histology of the hymenopterous poison apparatus, II: Pogonomyrmex badius (Formicidae). Annals of the Entomological Society of America 60: 661-668.

Hermann HR, Blum MS (1967b) The morphology and histology of the hymenopterous poison apparatus, III: Eciton hamatum (Formicidae). Annals of the Entomological Society of America 60: 1282-1291.

Hermann HR, Blum MS (1981) Defensive mechanisms in social Hymenoptera. In: Hermann HR (Ed) Social Insects, $2^{\text {nd }}$ vol. Academic Press Inc., New York, 77-197.

Hoell HV, Doyen JT, Purcell AH (1998) Introduction to insect biology and diversity. Oxford University Press, 320.

Hölldobler B, Wilson EO (1970) Recruitment trails in the harvester ant Pogonomyrmex badius. Psyche 77: 385-399. doi: 10.1155/1970/38470

Hölldobler B, Wilson EO (1990) The ants. Springer-Verlag, Berlin.

Hölldobler B, Wust M (1973) Ein sexualpheromon bei der Pharaoameise Monomorium pharaonis (L.). Zeitschrift für Tierpsychologie 32: 1-9. doi: 10.1111/j.1439-0310.1973. tb01092.x

Howard RW, Baker JE (2003) Morphology and chemistry of Dufour glands in four ectoparasitoids: Cephalonomia tarsalis, C. waterstoni (Hymenoptera: Bethylidae), Anisopteromalus calandrae, and Pteromalus cerealellae (Hymeoptera: Pteromalidae). Comparative Biochemistry and Physiology B 135: 153-167. doi: 10.1016/S1096-4959(03)00076-9

Howard RW, Baker JE, Morgan ED (2003) Novel diterpenoids and hydrocarbons in the Dufour gland of the ectoparasitoid Habrobracon hebetor (Say) (Hymenoptera: Braconidae). Archives of Insect Biochemistry and Physiology 54: 95-109. doi: 10.1002/arch.10104

Huang F, Shi M, Chen Y-F, Cao T-T, Chen X-X (2008) Oogenesis of Diadegma semiclausum (Hymenoptera: Ichneumonidae) and its associated polydnavirus. Microscopy Research and Technique 71: 676-683. doi: 10.1002/jemt.20594

Hubbard SF, Marris G, Reynolds A, Rowe GW (1987) Adaptive patterns in the avoidance of superparasitism by solitary parasitic wasps. Journal of Animal Ecology 56: 387-401. doi: $10.2307 / 5055$

Hunt JH (2007) The evolution of social wasps. Oxford University Press, New York. doi: 10.1093/acprof:oso/9780195307979.001.0001

Jeanne RL (1977) Behavior of the obligate social parasite, Vespula arctica (Hymenoptera: Vespidae). Journal of the Kansas Entomological Society 50: 541-577. 
Jeanson R, Ratnieks FLW, Deneubourg J-L (2003) Pheromone trail decay rates on different substrates in the Pharaoh's ant, Monomorium pharaonis. Physiological Entomology 28: 192-198. doi: 10.1046/j.1365-3032.2003.00332.x

Jin YX, Chen YY, Jiang YH, Xu MK (2006) Proteome analysis of the silkworm (Bombyx mori L.) colleterial gland during different developmental stages. Archives of Insect Biochemistry and Physiology 61: 42-50. doi: 10.1002/arch.20095

Katzav-Gozansky T, Hefetz A, Soroker V (2007) Brain modulation of Dufour's gland ester biosynthesis in vitro in the honeybee (Apis mellifera). Naturwissenschaften 94: 407-411. doi: 10.1007/s00114-006-0206-y

Katzav-Gozansky T, Soroker V, Hefetz A (1997) The biosynthesis of Dufour's gland constituents in queens of the honeybee (Apis mellifera). Invertebrate Neuroscience 3: 239-243. doi: 10.1007/BF02480380

Katzav-Gozansky T, Soroker V, Hefetz A (2002) Honeybees Dufour's gland - idiosyncrasy of a new queen signal. Apidologie 33: 525-537. doi: 10.1051/apido:2002035

Kjer KM (2004) Aligned 18S and insect phylogeny. Systematic Biology 53: 506-514. doi: $10.1080 / 10635150490445922$

Kristensen NP (1981) Phylogeny of insect orders. Annual Review of Entomology 26: 135-157. doi: 10.1146/annurev.en.26.010181.001031

Kronenberg S, Hefetz A (1984) Comparative analysis of Dufour's gland secretions of two carpenter bees (Xylocopinae: Anthophoridae) with different nesting habits. Comparative Biochemistry and Physiology B 79: 321-425. doi: 10.1016/0305-0491(84)90399-7

Landolt PJ, Akre RD (1979) Occurrence and location of exocrine glands in some social Vespidae (Hymenoptera). Annals of the Entomological Society of America 72: 141-148.

Lanne BS, Bergström G, Löfqvist J (1988) Dufour gland alkenes from the four ant species: $F$. polyctena, F. lugubris, F. truncorum, and F. uralensis. Comparative Biochemistry and Physiology 91B: 729-734. doi: 10.1016/0305-0491(88)90200-3

Law JH, Wilson EO, McCloskey JA (1965) Biochemical polymorphism in ants. Science 149: 544-545. doi: 10.1126/science.149.3683.544

Lawrence PO, Akin D (1990) Virus-like particles from the poison glands of the parasitic wasp Biosteres longicaudatus (Hymenoptera: Braconidae). Canadian Journal of Zoology 68: 539-546. doi: 10.1139/z90-079

Lello de E (1971a) Adxenal glands of the sting apparatus of bees: Anatomy and histology. I. (Hymenoptera: Colletidae and Andrenidae). Journal of Kansas Entomological Society 44: 5-13.

Lello de E (1971b) Adxenal glands of the sting apparatus of bees: Anatomy and histology. II. (Hymenoptera: Halictidae). Journal of Kansas Entomological Society 44: 14-20.

Malka O, Shnieor S, Katzav-Gozansky T, Hefetz A (2008) Aggressive reproductive competition among hopelessly queenless honeybee workers triggered by pheromone signaling. Naturwissenschaften 95: 553-559. doi: 10.1007/s00114-008-0358-z

Marris GC, Hubbard SF, Scrimgeour C (1996) The perception of genetic similarity by the solitary parthenogenetic parasitoid Venturia canescens, and its effects on the occurrence of superparasitism. Entomologia Experimentalis et Applicata 78: 167-174. doi: 10.1007/ BF00187513 
Martin SJ, Châline N, Oldroyd BP, Jones GR, Ratnieks FLW (2004) Egg marking pheromones of anarchistic worker honeybees (Apis mellifera). Behavioral Ecology 15: 839-844. doi: 10.1093/beheco/arh089

Maschwitz U, Kloft W (1971) Morphology and function of the venom apparatus of insectsbees, wasps, ants and caterpilars. In: Bucherl W, Buckley EE (Eds) Venomous AnimaIs and their venoms, $3^{\text {rd }}$ vol. Academic Press, New York, 1-59.

Mehrnejad MR, Copland MJW (2007) Host discrimination by the endoparasitoid Psyllaephagus pistaciae (Hymenoptera: Encyrtidae): a case of time-dependent ability. Biocontrol Science and Technology 17: 401-411. doi: 10.1080/09583150701309196

Mitra A, Gadagkar R (2011) Can Dufour's gland compounds honestly signal fertility in the primitively eusocial wasp Ropalidia marginata? Naturwissenschaften 98: 157-161. doi: 10.1007/s00114-010-0749-9

Mitra A, Gadagkar R (2012a) Queen signal should be honest to be involved in maintenance of eusociality: chemical correlates of fertility in Ropalidia marginata. Insectes Sociaux 59: 251-255. doi: 10.1007/s00040-011-0214-6

Mitra A, Gadagkar R (2012b) Road to royalty - transition of potential queen to queen in the primitively eusocial wasp Ropalidia marginata. Ethology 118: 694-702. doi: 10.1111/j.1439-0310.2012.02059.x

Mitra A, Saha P, Chaoulideer ME, Bhadra A, Gadagkar R (2011) Chemical communication in Ropalidia marginata: Dufour's gland contains queen signal that is perceived across colonies and does not contain colony signal. Journal of Insect Physiology 57: 280-284. doi: 10.1016/j.jinsphys.2010.11.014

Mitra A, Gadagkar R (in press) Dufour's gland and cuticle in the social wasp Ropalidia marginata contain the same hydrocarbons in similar proportions. Journal of Insect Science.

Morgan ED (2009) Trail pheromones of ants. Physiological Entomology 34: 1-17. doi: 10.1111/j.1365-3032.2008.00658.x

Mori A, Grasso DA, Visicchio R, Le Moli F (2000) Colony founding in Polyergus rufescens: the role of the Dufour's gland. Insectes Sociaux 47: 7-10. doi: 10.1007/s000400050002

Mudd A, Fisher RC, Smith MC (1982) Volatile hydrocarbons in the Dufour's gland of the parasite Nemestris canescens (Grav.) (Hymenoptera: Ichneumonidae). Journal of Chemical Ecology 8: 1035-1042. doi: 10.1007/BF00987884

Noirot C, Quennedy A (1974) Fine structure of insect epidermal glands. Annual Review of Entomology 19: 61-80. doi: 10.1146/annurev.en.19.010174.000425

Norden BB, Batra SWT, Fales HM, Hefetz A, Shaw JC (1980) Anthophora bees; unusual glycerides from maternal Dufour's glands serve as larval food and cell lining. Science 207: 1095-1097. doi: 10.1126/science.207.4435.1095

Oldham N, Billen J, Morgan ED (1994) On the similarity of the Dufour gland secretion and the cuticular hydrocarbons of some bumblebees. Physiological Entomology 19: 115-123. doi: 10.1111/j.1365-3032.1994.tb01084.x

Oldroyd BP, Ratnieks FLW, Wossler TC (2002) Egg-marking pheromones in honey-bees Apis mellifera. Behavioral Ecology Sociobiology 51: 590-591. doi: 10.1007/s00265002-0480-4 
Patricio E, Cruz Lopez L, Maile R, Morgan DE (2003) Secretions of stingless bees: the Dufour glands of some Frieseomelitta species (Apidae, Meliponinae). Apidologie 34: 359-365. doi: 10.1051/apido:2003027

Pau RN, Brunet PCJ, Williams MJ (1971) The isolation and characterization of proteins from the left colleterial gland of the cockroach, Periplaneta americana (L.). Proceedings of the Royal Society of London B 177: 565-579. doi: 10.1098/rspb.1971.0048

Rasnitsyn AP (2002) Class Insecta Linné, 1758. The insects (=Scarabaeoda Laicharting, 1781). In: Rasnitsyn AP, Quicke DLJ (Eds) History of insects. Kluwer Academic Publishers, Dordrecht, Netherlands, 243. doi: 10.1007/0-306-47577-4_2

Rasnitsyn AP, Zhang H (2010) Early evolution of Apocrita (Insecta, Hymenoptera) as indicated by new findings in the middle Jurassic of Daohugou, northeast China. Acta Geologica Sinica 84: 834-873. doi: 10.1111/j.1755-6724.2010.00254.x

Reed HC (1982) Biology and behavior of the forest yellowjacket, Vespula acadica (Sladen) and the obligate social parasite, Vespula austraica (Panzer) (Hymenoptera: Vespidae). PHD Thesis. Washington State University, Pullman.

Reed HC, Akre RD (1982) Morphological comparisons between the obligate social parasite, Vespula austraica (Panzer), and its host, Vespula acadica (Sladen) (Hymenoptera: Vespidae). Psyche 89: 183-196. doi: 10.1155/1982/52306

Richard F-J, Schal C, Tarpy DR, Grozinger CM (2011) Effects of instrumental insemination and insemination quantity on Dufour's gland chemical profiles and vitellogenin expression in honey bee queens (Apis mellifera). Journal of Chemical Ecology 37: 1027-1036. doi: 10.1007/s10886-011-9999-z

Ritter FJ, Brüggemann-Rotgans IEM, Verwiel PEJ, Persoons CJ, Taiman E (1977) Trail pheromones of the Pharaoh's ant, Monomorium pharaonis: isolation and identification of Farnal, a terpenoid related to juvenile hormone II. Tetrahedron Letters (London) 30: 2617-2618. doi: 10.1016/S0040-4039(01)83835-1

Robertson PL (1968) A morphological and functional study of the venom apparatus in representatives of some major groups of Hymenoptera. Australian Journal of Zoology 16: 133-166. doi: 10.1071/ZO9680133

Rosi MC, Isidoro N, Colazza S, Bin F (2001) Source of the host marking pheromone in the egg parasitoid Trissolcus basalis (Hymenoptera: Scelionidae). Journal of Insect Physiology 47: 989-995. doi: 10.1016/S0022-1910(01)00073-7

Ruano F, Hefetz A, Lenoir A, Francke W, Tinaut A (2005) Dufour's gland secretion as repellent used during usurpation in the slave-maker ant Rossomyrmex minuchae. Journal of Insect Physiology 51: 1158-1164. doi: 10.1016/j.jinsphys.2005.06.005

Schmitz J, Moritz RFA (1998) Molecular phylogeny of Vespidae (Hymenoptera) and the evolution of sociality in wasps. Molecular Phylogenetics and Evolution 9: 183-191. doi: 10.1006/mpev. 1997.0460

Shimron O, Hefetz A, Tengö J (1985) Structural and communicative functions of Dufour's gland secretion in Eucera palestinae (Hymenoptera: Anthophoridae). Insect Biochemistry 15: 635-638. doi: 10.1016/0020-1790(85)90126-X

Simser H, Coppel HC (1980) Female-produced sex pheromone in Brachymeria lasus and B. intermedia (Hym.: Chalcididae). Biocontrol 25: 373-380. doi: 10.1007/BF02374700 
Sledge MF, Fortunato A, Turillazzi S, Francescato E, Hashim R, Moneti G, Jones GR (2000) Use of Dufour's gland secretion in nest defence and brood nutrition by hover wasps (Hymenoptera, Stenogastrinae). Journal of Insect Physiology 46: 753-761. doi: 10.1016/ S0022-1910(99)00164-X

Smith BH, Carlson TG, Frazier J (1985) Identification and bioassay of macrocyclic lactone sex pheromone of the halictine bee Lasioglossum zephyrum. Journal of Chemical Ecology 11: 1447-1456. doi: 10.1007/BF01012144

Smith BH, Wenzel JW (1988) Pheromonal covariation and kinship in social bee Lasioglossum zephyrum (Hymenoptera: Halictidae). Journal of Chemical Ecology 14: 87-94. doi: $10.1007 / \mathrm{BF} 01022533$

Sole CL, Kryger P, Hefetz A, Katzav-Gozansky T, Crewe RM (2002) Mimicry of queen Dufour's gland secretions by workers of Apis mellifera scutellata and $A$. m. capensis. Naturwissenschaften 89: 561-564. doi: 10.1007/s00114-002-0370-7

Soro A, Ayasse M, Zobel MU, Paxton RJ (2011) Kin discriminators in the eusocial sweat bee Lasioglossum malachurum: the reliability of cuticular and Dufour's gland odours. Behavioral Ecology and Sociobiology 65: 641-653. doi: 10.1007/s00265-010-1066-1

Stephen WP, Torchio PF (1961) Biological observation on Emphoropsis miserabilis (Cresson) with comparative notes on other anthophorids. Annals of the Entomological Society of America 54: 687-692.

Stoka AM (1999) Phylogeny and evolution of chemical communication: an endocrine approach. Journal of Molecular Endocrinology 22: 207-225. doi: 10.1677/jme.0.0220207

Strohm E, Linsenmair KE (2001) Females of the European beewolf preserve their honeybee prey against competing fungi. Ecological Entomology 26: 198-203. doi: 10.1046/j.13652311.2001.00300.x

Sugumaran M, Nellaiappan K (1990) On the latency and nature of phenoloxidase present in the left colleterial gland of the cockroach Periplaneta americana. Archives of Insect Biochemistry and Physiology 15: 165-181. doi: 10.1002/arch.940150305

Syvertsen TC, Jackson LL, Blomquist GJ, Vinson SB (1995) Alkadienes mediating courtship in the parasitoid Cardiochiles nigriceps (Hymenoptera: Braconidae). Journal of Chemical Ecology 21: 1971-1989. doi: 10.1007/BF02033856

Tengö J, Bergström G (1977) Cleptoparasitism and odor mimetism in bees: do Nomada males imitate the odor of Andrena females? Science 196: 1117-1119. doi: 10.1126/science.196.4294.1117

Tengö J, Hefetz A, Bertsch A, Schmitt U, Lübke G, Francke W (1991) Species specificity and complexity of Dufour's gland secretion of bumble bees. Comparative Biochemistry and Physiology 99B: 641-646. doi: 10.1016/0305-0491(91)90348-H

Topoff H, Cover S, Greenberg L, Goodloe L, Sherman P (1988) Colony founding by queens of the obligatory slave-making ant, Polyergus breviceps: the role of the Dufour's gland. Ethology 78: 209-218. doi: 10.1111/j.1439-0310.1988.tb00231.x

Traniello JFA (1980) Colony specificity in the trail pheromone of an ant. Naturwissenschaften 67: 361-362. doi: 10.1007/BF01106597

Turillazzi S (1989) The origin and evolution of social life in the Stenogastrinae (Hymenoptera, Vespidae). Journal of Insect Behavior 2: 649-661. doi: 10.1007/BF01065784 
Ueno T (1994) Self-recognition by the parasitic wasp Itoplectis naranyae (Hymenoptera: Ichneumonidae). Oikos 70: 333-339. doi: 10.2307/3545770

Van Marle J, Piek T (1986) Morphology of the venom apparatus. In: Piek T (Ed) Venoms of the Hymenoptera. Academic Press, London, 17-44.

Vardal H (2006) Venom gland and reservoir morphology in cynipoid wasps. Arthropod Structure and Development 35: 127-136. doi: 10.1016/j.asd.2006.05.002

Vincent B, Kaeslin M, Roth T, Heller M, Poulain J, Cousserans F, Schaller J, Poirie M, Lanzerin B, Drezen J-M, Moreau SJM (2010) The venom composition of the parasitic wasp Chelonus inanitus resolved by combined expressed sequence tags analysis and proteomic approach. BMC Genetics 11: 693. doi: 10.1186/1471-2164-11-693

Vinson SB (1978) Courtship behavior and source of a sexual pheromone from Cardiochiles nigriceps. Annals of the Entomological Society of America 71: 832-837.

Vinson SB, Frankie GW, Blum MS, Wheeler JW (1978) Isolation, identification and function of Dufour's gland secretion of Xylocopa virginica texana (Hymenoptera: Anthophoridae). Journal of Chemical Ecology 4: 315-323. doi: 10.1007/BF00989340

Vinson SB, Guillot FS (1972) Host marking: Source of a substance that results in host discrimination in insect parasitoids. Biocontrol 17: 241-245. doi: 10.1007/BF02371134

Whitehouse MEA, Jaffe K (1996) Ant wars: combat strategies, territory and nest defence in the leaf-cutting ant Atta laevigata. Animal Behaviour 51: 1207-1217. doi: 10.1006/ anbe. 1996.0126

Whitfield JB (1992) Phylogeny of the non-Aculeate Apocrita and the evolution of parasitism in the Hymenoptera. Journal of Hymenoptera Research 1: 3-14.

Whitfield JB, Cameron SA (1998) Hierarchical analysis of variation in the mitochondrial 16S rRNA gene among Hymenoptera. Molecular Biology and Evolution 15: 1728-1743. doi: 10.1093/oxfordjournals.molbev.a025899

Whiting MF (2002) Phylogeny of the holometabolous insect orders: molecular evidence. Zoologica Scripta 31: 3-15. doi: 10.1046/j.0300-3256.2001.00093.x

Williams HJ, Strand MR, Vinson SB (1981) Trail pheromone of the red imported fire ant Solenopsis invicta (Buren). Cellular and Molecular Life Sciences 37: 1159-1160. doi: 10.1007/BF01989893

Wilson EO, Regnier FE Jr. (1971) The evolution of the alarm-defense system in the Formicine ants. The American Naturalist 105: 279-289. doi: 10.1086/282724 